\title{
Site Investigator
}

National Cancer Institute

\section{Source}

National Cancer Institute. Site Investigator. NCI Thesaurus. Code C51873.

An investigator designated to a specific study location. 